The Geneva Papers on Risk and Insurance, 16 (No. 58, January 1991), 85 -92

\title{
The Czechoslovak Insurance Industry and Insurance Science at the Dawn of a New Epoch*
}

\author{
by Vojtěch Bočinsky**
}

\section{A few words on history}

As ghost, around both czechoslovak insurance institutions, prowl the unmelodious words, unaccustomed and hard to pronounce, such as demonopolization, de-statization, commercialization. They scare mostly those who got used to comfort and lack of worries, who do not appreciate innovations and do not know what personal initiative is, who are always waiting for orders from above, indifferent to the quality of their own work.

The rich history of the czech insurance industry demonstrates that our fellow citizens have, and always had, a feeling for the idea of seeking security from the threats of casual events. Though the first insurance institutions that operated on the territory of today's Czechoslovakia were austrian, the first, genuinely czech (mutual) insurance company emerged in 1827, whereas the first professional reinsurance corporation, the Bohemian $\mathrm{Re}$ Bank, was founded in Prague in 1872. The fact that, from 1911 to 1922, the well-known writer Franz Kafka worked in the Arbeiter Unfallversicherung on the Old Town Square in Prague is an interesting historical circumstance. Some not very serious researchers affirm that it was precisely his work in the insurance company that plunged this sensitive young man into a deep gloom...

During the period between the two World Wars, the number of insurance companies on the czechoslovak market fluctuated between 600 and 700 . Czech and slovak insurance companies were exposed to a cruel competitive struggle with foreign capital which spread towards our territory mainly from Germany, Italy, Austria and England. Some czech societies, such as the Slavia Insurance Company or the First Bohemian Re Bank, reached then european fame. In the thirties, the great scandal linked with the crash of an important company, the Phoenix, dealt a great blow to the development of the insurance industry. This event affected the trust on the part of the population towards the insurance industry; this was partially reflected in the fact that in 1945, the idea of nationalizing it did not meet with a great resistance in post-war Czechoslovakia.

* This and the following three papers have bcen presented and discussed at a conference organized by the Geneva Association in Vienna, September 17, 1990.

** Czech State Insurance Corp., Prague. Text presented - as well as the three following ones - at the Conference on Insurance in Eastern Europe, organized by the Geneva Association in Vienna, 17 September, 1990.

Warning: The author's opinions do not necessarily coincide with those of the czechoslovak insurance corporations' management or their superior authorities. 


\section{After 1945: largo desolato}

The political evolution after World War II led to the nationalization of insurance on 24 Oct. 1945. 734 registered insurance companies were nationalized and, in 1947, gradually merged into 5 and finally, by 1953, into one: the Czcchoslovak State Insurance Corporation, a national enterprise. In 1958, the First Bohemian Re Bank was incorporated into the State Insurance Corp. This completed the organizational aspect of the ccntralization proccss, creating the monopoly of insurance and rcinsurancc activities in Czechoslovakia. Since its very beginning, it was accompanied by the consequences of the general legal nihilism. which, in the insurance industry, led to a sharp rcduction of employees working in insurance, and to a Ministry of Finance resolution prohibiting the insurance of national (State) property, except the part that was object of foreign trade. This prohibition, which included the great majority of industrial cntcrprises, lasted until 1967, when the Insurance Corporation was again allowed to resumc the insuring of industrial organizations. (Uzel, 4).

The later development of the industry, especially the life insurance branch, was catastrophically influcnced by the monetary reform of 1953, when the insurance benefits were calculated in an extremely unfavorable proportion. Thereafter only one innovation, which hardly has its peer in insurance of persons anywhere else, was made in Czechoslovakia: Since people did not trust life insurance any more, the personal injury insurance became the support on which further evolution rested. In the late fifties, a hybrid combination of personal injury and life insurance in one comprehensive policy began to be promoted, with the life insurance being taken at first only as a complement of the personal injury policy. The consequences of this development sui generis have persisted up to now: the comprehensive insurance of persons including life and personal injury has become one of the preferred and most successful products. If, in the future, we want to adopt the EC rules, and separate life strictly from other classes of insurance, we shall be confronted by a particularly troublesome problem.

The legal frame of the insurance industry is based on the Law \# 82/66 Coll. Of Laws, amended by the Law\# 162/88 Coll. of Laws. According to this law, the exclusive right to operate in the field of contractual and compulsory insurance, including insurance derived from international trade and reinsurance, belongs to the Czech State Insurance Corp. with its head office in Prague, and to the Slovak State Insurance Corp. with its head office in Bratislava. From 1. 1. 1969 on, both insurance corporations enjoy the statute of economic organizations with a national ambit. Nothing prevents them from compcting with cach othcr. However, they made a deal determining their territorial spheres of influence and the forms of mutual cooperation. (Compare with Uzcl, 4).

The rigid conception of the catcgorics of productive work, and productive economic activities, as used in the socialist political-cconomic theory of the past to a considerable degree, affected negatively the socio-economic prestige of the insurance industry. Its classification among the non-productive services meant a limitation of the capacities and financial resources of the czechoslovak insurance institutions by administrative commands; in these circumstances, the profits were considered only as the result of redistribution processes (compare with Daňhcl, 3).

Insurance, being a typical instrument of the monetary cconomy on a commcrcial basis, bccame a foreign body in a stiff economic system run by administrative command. That is why, in the course of the history of a socialist economy now on the wane, the theoreticians 
from all the socialist countries so clumsily searched for the answer to the theoretical questions concerning the function of insurance in the socialist economic model, particularly the question of the purposefulness, functionality, even the acceptability of creating insurance funds to satisfy the necessitics of the nationalized industry.

The Central Authoritics created a scrics of administrative instruments in order to keep the "foreign body" that constituted the insurance industry properly under control. In the initial phase of the rigid command economic system, the Head Office of the State Insurance Institute was a component of the Ministry of Finance. This link between the State Administration and the cxecutive units of the insurance industry obviously fully fits into this economic model. However, the Insurance Corporation remained under direct administrative control of the Ministry of Finance even after the "scparation from the State" in the early sixties. The insurance industry, being a rathcr heterogcneous element in the whole system, was constantly stifled in its development by administrative interventions from the Center. To this end scrved the incongruous fiscal policy, the severe rcsourcc restrictions, the setting of material and personnel top limits, and so on. Also, the separation of the top management of the Insurance Corporation from the Ministry of Finance deprived the State of a body of specialists fit to govern or supervise the insurance activitics. Theorctically, the Center had enough instruments to govern the insurance industry, but in practice it limited itself to a mere assigning of planned quantities, often arrived at cmpirically.

In the period of the rigid planned economy, the insurance industry became a marginal branch of the economy. To this also contributed the suspension of the financial market and large taxes due to a high profitability of some insurance branches. For the authorities, therefore, the importance of insurance consisted mainly in absorbing part of the purchasing power. (Compare with Vostatek, 1).

In connection with the marginal status of insurance, the theoreticians often forgot to consider the impact of contingency on human economic activities. A systematic and complex approach to the anticipation of contingency and risk in planning and management and in the materialization of scientific-technical development was. and still remains, on the fringes of scientific interest.

\section{The evolution of the insurance industry in monopoly conditions : The unbearable lightness of being}

However, the numerous limiting factors, derived from the rigid command economic system, exertcd a relatively small influcncc ovcr the insurance industry. The extrcmely critical period that followed the monetary reform (1953) was marked by an unusual burst of innovative activity. Czcchoslovakia then became one of the pioneers of associated forms of insurancc policies which became vcry popular (particularly the comprehensive household insurance, the houseowner insurance, the comprehcnsive insurance of persons covering life and pcrsonal injury). The insurance of industrial enterpriscs was reintroduced in 1967.

In spite of the low level of competence and lack of flexibility on the part of hierarchically superior authorities, from the early sixties on, the insurance industry developed much morc dynamically than most other branches of the national economy. The monopolistic position of the insurance institutions had, on onc hand, a scries of unfavorablc consequences: limited assortment of products offered, excessive concentration in covering standard risks, slow rcsponse to the emergence of new insurance interests, indifferent 
quality of the services etc. On the other hand, it also brought some positive elements: a high standardization of the insurance protection linked with a considerable reduction of administrative costs and a lowering of the insurance premiums.

Czechoslovakia can be considered a country where people have a penchant for insurance. Both insurance enterprises offer all the traditional classes of life and non-life insurance. Motor third-party liability, public air carrier and hunters liability, as well as the integral erop and livestock insurance have a compulsory or cven statutory form. Generally, a high insurance density has been reached: e. g. in the houseowner's insurance nearly $100 \%$, household insurance $75 \%$, and motor hull nearly $50 \%$. In 1989, the volume of premium income has reached 22.664 million CSK; a $12 \%$ increase compared to the previous ycar, with the annual inflation rate estimated at about $3 \%$. Although the development of the insurance activity suffered because the insurance institutions had to fulfill with priority certain imaginary planned tasks in harmony with the state financial and fiscal policy, it became an instrument that influenced effectively the stability of the reproductive process and the whole socio-economic development of the society.

The insurance corporations' management found itself involved in paradoxical situations. On one hand, the monopoly guaranteed a wide field of action without the need to worry about competition, on the other hand, they had to respect planned indices and directive commands, often economically doubtful ones. The consequences of this led to an empirical, intuitive style of management that prescinded of scientific bases. Actuarial mathematics preserved its importance in life and pension insurance, but elsewhere it was freely substituted by the empirical approach, risk management did not sprout even the thinnest roots, insurance law ceased to be a scientific discipline. The preparation of specialists in universities corresponded, and still correspond, to these conditions: the science of insurance is practically not taught at all. Only the Superior Schools of Economy in Prague and Bratislava graduate a small group of insurance-oriented economists every year.

The majority of executives and specialists in the insurance industry were interested in the development of their branch and the broadening and improvement of its services. The monopoly, from their point of view, apparently offered numerous advantages: low costs, inexpensive services, no limits set by the competition, a relatively free tariff determination, the possibility of compensation between the different insurance classes, etc. However, the good intentions often could not be put into practice, impeded by the necessity to respect numerous indices and limits. One example: the size of the population in Czechoslovakia is approximately double that of Austria, yet the proportion of those who work in insurance is exactly the oppositc. Only in 1989 have the restrictions on the total number of employees been partly relaxed, but employment has not increased significantly until this year.

In spite of all the limitations, the insurance industry has developed over the past years as a branch of the economy markedly above the national average; of course, the fact that the quality of the services did not improve and even got worse was the price that had to be paid. Considering the increase of the premium income volume and the profit transference to the State Budget, we were termed a success, but inside us grew an uneasy feeling that somehow the main thing, that is, the customers' satisfaction, was out of our reach. Thus the czech exiled writer's Milan Kundera's, metaphor "unbearable lightness of being" can also 
be applied to the feclings of those who, in the seventies and eighties, took part in working out the stratcgic projection for the czechoslovak insurance industry.

\section{Perspectives of insurance industry development in a changed political-economic environment: Transformatio tremens.}

The present situation in the czcchoslovak insurance industry can be described as tense and transitional: the monopoly status of both national insurance corporation persists, but cvidently is approaching its epilogue. The new law abrogating the monopoly and establishing new rules of the game should be put into effect by the beginning of 1991. For the year 1990, the superior authorities have set the direct transfer of a reduced share of profits to the State Budget and the payroll tax as the only obligatory indices, otherwise they do not interfere with the corporations activitics. The ideas of how the state supervision over the insurance industry will operate are being shaped. Many domestic economic subjects, but especially foreign insurance companies are getting ready to enter the czechoslovak pluralistic insurancc market as soon as the lcgal regulations permit.

Evidently, for the existing national insurance corporations, the transition from monopoly to pluralistic market is not simple. In spite of that, they are decided to contribute to this process with a fair-play approach, in the spirit of the "quiet revolution": they collaborate on the preparation of the new law on insurance and strive to ensure from the very beginning the functioning of a just state supervision that is to guarantee equal starting conditions to all parties, and to protect the policy-holders from the snares of a pluralistic insurance market. The foundation of an insurance bank is being considered, to which the newly emerging insurance companies could look for support when investing their capital reserves, when in need of credits etc. Also, both existing insurance corporations are anxious for the universities to create conditions for the training of a greater number of highly-educated staff for the insurance industry, and they intend to open a specialized training institute.

Both state insurance corporations are ready to take up a new role in the new conditions. It is expected that in a first phase, they will be transformed into stock companies with a strong majority proportion of state capital, and the question is how fast and how much the state share will diminish later.

They both must face many obstacles generated by the new economic environment: there are complications brought about by the projection of the liberalization of prices into the claim settlements, complications connected with the danger of unbalance in loss experience in property and liability insurance, a higher inflation rate is expected, and the inadcquatc knowledge and lack of experience of the staff with the working of the market economy mechanism will be a drag.

One of the fairly probable scenarios of the future development of the insurance market in CSFR predicts that the Czech State Insurance Corporation will take advantage of its relatively strong capital assets to create various joint ventures specializing in different types of insurance. Of course, the choice of potcntial partners to found ncw enterprises will be regulated by certain fixed rules, and an important role will be played by the offers of know-how and new products, information and communication tcchnologies, and possibly offers of training programs for selectcd catcgorics of employees, for example actuarial mathematicians or spccialized marketeers. 


\section{Impacts on the insurance theory: So far, question marks prevail}

The revolutionary political and economic changes in Czechoslovak society logically have a serious impact on the interpretation of social, and therefore also economic, sciences. The rejection of marxism-leninism as the exclusive philosophical and methodological starting point evidently manifests itself in insurance theory and policy, because these are an integral part of the financial theory and policy. The general objection to the financial sciencies is now formulatcd in our country from the positions of macroeconomic modelling: financial theory gradually constituted itself as a verbal and not wholly consistent science, without firm foundations, inadequately mathematized, and its formal expression practically unverifiable (Bulír, 8).

This still applies to our insurance theory with all its consequences on insurance practice: it manifests itself especially in the insufficient mathematical modelling of the premium rate calculations. There are disproportions affecting the czech insurance tariffs, the elimination of which will be the none too easy task of the months to comc. The condition for a new insurancc institutions tariff policy is in the first place to prevent the possibility of a fiscal abuse of insurance and then to reinstate the use of exact approaches to the premium calculations.

While we are confronted with the de-statization and privatization of insurance institutions, another important theoretical issue emerges; it has already manifested itself in other countries too, but so far it has not been dealt with satisfactorily nor without ambiguities: How are the insurance companies' reserve funds to be viewed before partial privatization? Most specialists in our country are of the opinion that the mathematical reserves of the life and old-age pension insurance continue to be the property of the policy-holders who entrusted their money to the insurance company in good faith, to be kept until the occurrence of an insurance event, or until the policy-holder reaches the age that has been agreed upon. The reserve funds of non-life policies are considered in a different light. Here the policy-holders have paid in advance for a service under contract, which the insurance company is obliged to fulfill, if a certain event, specified in the contract or in the insurance conditions, takes place. Therefore, the reserves derived from services thus paid for in advance are unquestionably the property of the insurance company. However, there are other points of view on the determination of the property and legal aspects before the transformation process is initiated. For example, it is a disputcd question whether the state, as owner of the insurance company, is justified in laying claim to these funds, at least to the cxtcnt that corresponds to the premiss that, in case of long-term insurance, every owner counts on the long-term disponibility of the reserves and on the yields from the invested capital. We would welcome if the representatives of world insurance theory would take a stand on this matter.

Another important theoretical issue is the function of the insurance institutions and their part in an accelerated shaping of a full-blooded capital market. This is above all linked with the requirement of a maximum freedom to manage and invest the reserve capital.

I have already mentioned the negative consequences of a static perception of the categories of productive work and productive economic activities in the political economy of not so long ago on the low social prestige of the insurance busincss. A classification, not well backed theoretically, which lumped insurance with non-productive serviccs, Icd to 
the already mentioned limitations of capacities and financial resources needed to organize the further development of our branch. The fact that insurance constitutes a condition or a factor of the productive process was overlooked. Insurance is an element of the economic infrastructurc, it is an instrument that influences the stability of the productive process and a means for the satisfaction of necessities in the process of consumption. Thus it is a source of the social-economic development of society and in this context it must be considered a service to production (Daňhel, 6).

A macro-view of insurance as part of the economic infrastructure should help us to find the way to integrate it more fully within the system of economic policy and contribute as much as it can to activize the financial mechanism in the incipient process of the monetarization of the economy. The concentration of the financial means will promote a redistribution of resources along desirable lines, and a reduction of inflationary pressures as well. Compare with Daňhcl, 6.

Evidently, our first step must be to remove the ideological silt from contemporary insurance science, even though its layer may be relatively thin. However, the theoretical front in the sphere of insurance and related scientific disciplines (risk management, loss prevention etc.), until now rather underestimated, should be considerably strengthened. The broadening of the teaching of insurance at the Superior Schools of Economy in Prague and Bratislava, starting this September, constitutes a first partial success; however, I consider that the key solution will be the founding of a Research and Training Institute for the czechoslovak insurance industry. When laying down the strategic orientation line of this institute, we base ourselves above all on the accumulated knowledge and experience of the British Chartered Insurance Institute, german training institutes, the polish institute at Radom, the austrian training institute, as well as other institutions.

\section{Conclusion: The carnival is over and a weekday is dawning}

Our Federal Government that arose from the first free elections after 44 years, is concluding at present a more profound version of the basic theses of its economic reform and transformation program. It looks as if the orientation towards a full application of all the levers of the market economy and the gradual approximation to the principles prevalent in the European Community already were irreversible and the speculations about the search for some third way, which certain specialists call "the third way into the Third World", have becn conjured. Evidently, there is no third way, for the insurance industry ncither, so we are preparing a program for the application of norms approaching the EC standards.

The majority of those who work in the insurance sphere are conscious that a new era of unusual insurance boom lies ahead, but it will have to be paid for by a few critical years of transcendental changes and confusions. Practically everything will changc: the insurance of agricultural risks will be transferred to a voluntary basis, the insurance of industrial risks will undergo a fundamental change, because of the changes in ownership of the enterprises, the dismcmberments of largc concerns into smallcr, independent units, the expected disappearance of a series of enterprises and the founding of new ones with new insurance requirements. In the sphere of the insurance of persons, the considerable differentiation of incomes will manifest itself in the differentiation of insurance demands. At the same time, it will also be necessary to face inflation and foreign competition. 
Thus the initial euphoria that followed the success of the velvet revolution soon began to fade. The oppressive heritage of the past evidently cannot be overcome as quickly as we first imagined.

President Václav Havel best expressed our present state of mind at the traditional opening address of this year's Salzburg Music Festival in July: "We understand that the poetry has run its course and prose is beginning. The carnival is over and a weekday is dawning. Only now we realize how much difficult and totally ungrateful work is in store. As if the wild rush of events had not allowed us to stand back, reflect, ponder whether we are equal to the tasks we have accepted... Contrary to the times of totality, when future was poor, but certain, to many it seems today most uncertain. The river of life used to have a narrow bed, but its edges were clear to all. Nowadays we do not know where those edges lie, and feel shocked."

However, it is not so bad that we should sink into gloom like the insurance clerk Franz Kafka almost 70 years ago. If the czechoslovak insurance industry prospered in political-economic conditions that were basically adverse, there is no reason to lose optimism because of the fact that in the nearest future the socio-economic transformation will constitute an extremely difficult test for the czechoslovak insurance industry.

\section{REFERENCES}

1) VOSTATEK, J.: Model of Managing the Insurance Industry under Socialism. Pojistné rozpravy Nr. 1.

2) VOSTATEK, J.: Obnova státního dozoru nad pojištovnictvím - klíčový prvek radikální reformy čs pojištění. (Reintroduction of State Supervision over the Insurance Industry - Key Element in the Radical Reform of the Czechoslovak Insurance Industry): Pojistné rozpravy Nr. 2.

3) DAŇHEL, J,: Př̀nese nové ekonomické klima zvýšení prestiže pojištěnú? (Will the New Economic Climate Raise the Prestige of the Insurance Industry?). Not yet published.

4) UZEL, V.: Implications of Insurance Activities during the Transition of Central-European Economic System. Lecture delivered at the Erasmus Universiteit, June 1990.

5) BOČINSKÝ, V.: Dokážeme sami zrušit svǔj monopol? (Will We Be Able to Abolish Our Monopoly by Oursclves?). Pojistný obzor Nr. 2/1990.

6) DAŇHEL、 J.: K některým aktuálním otázkám pojistné tcorie a politiky (Some Relevant Questions in Insurance Theory and Policy). Pojistný obzor Nr. 2 / 1990.

7) FRAUENTERKOVÁ, I.: Jak dál v pojistné teorii? (How Shall We Progress in Insurance Theory?). Pojistné rozpravy Nr. 2.

8) BULIR, A.: Monetární makroekonomic pro pokročilé. (Monetary Macroeconomy for Advanced Students). Finance a úvěr Nr. 7 / 1989. (Review). 